\title{
THE LEGAL IMPLICATIONS OF PASSIVE SMOKING AT HOME
}

\section{Benjamin Andoh, Law School, Southampton Institute}

Irrespective of whether it takes place at work or at home, passive smoking is the involuntary inhalation of the tobacco smoke of other people. The smoke inhaled by the non-smoker may be: (a) mainstream smoke: smoke inhaled and exhaled by the smoker, (b) sidestream smoke: smoke which is emitted directly from burning tobacco, or (c) environmental tobacco smoke, also known as second-hand smoke: a combination of both mainstream smoke and sidestream smoke in the atmosphere. ${ }^{1}$ In this article passive smoking will be used synonymously with involuntary exposure to environmental smoke.

There is today ample, in fact overwhelming, evidence of the harmful effects of environmental tobacco smoke. But, although there is protection given to individuals from violent acts (battery, and so forth) and from the effects of passive smoking in the workplace, ${ }^{2}$ there is no express protection of children and spouses (non-smoking) from environmental tobacco smoke in the home. This lack of protection is unsatisfactory because children, especially babies who cannot crawl, walk or run, do not have a choice but to continue to inhale the unwanted smoke of their parents at home and suffer the ill effects thereof. They also lack the means to leave the home at their own instance. As research has shown, the vast majority of people spend around $90 \%$ of their time in two very important microenvironments: work and home. ${ }^{3}$ Hence the importance of the legal implications of passive smoking at home. ${ }^{4}$

The present law, however, has certain unsatisfactory features. For example, exposure of children to passive smoking at home is not treated as child abuse

* I wish to thank Prof. Brigid Hadfield, the present editor David Capper, and the members of the Staff Research Group at the Law School, Southampton Institute for their comments on an earlier draft. Any error/s are mine.

1 Byrd, Shapiro, and Schiedermayer, "Passive Smoking: a review of medical and legal issues", (1989) 199(79) Am J Public Health, 209-13; Environmental Protection Agency, Respiratory Health Effects of Passive Smoking: Lung Cancer and Other Disorders, 3-1 (1992).

2 See, for example, Management of Health and Safety at Work: Approved Code of Practice (1992); and Regulation 6 of the Workplace (Health, Safety and Welfare) Regulations 1992 (SI 1992 No 3004). See also Waltons and Morse v Dorrington [1997] IRLR 488, where the duty to provide a safe system of work was extended via judicial creation of a new term implied by law in a contract of employment: ". . . the employer will provide and monitor for his employees, so far as is reasonably practicable, a working environment which is reasonably suitable for the performance by them of their contractual duties". An employee in that case was, therefore, entitled to resign and claim constructive dismissal because of the failure of her employer to remove her from a working environment polluted by smoking.

3 Salai, The Use of Time: Daily Activities of Urban and Suburban Populations in Twelve Countries (1972).

4 For its legal consequences in the workplace see Andoh, "Passive Smoking at Work Legal Implications for the Employer", (1998) 3(10) Health Law, Nov, pp 4-7, and (1998) 4(1) Health Law, pp 5-6. 
and exposure of a spouse to the same harmful effects as spousal abuse, ${ }^{5}$ also, a pregnant woman who smokes may be said, morally, to be harming the foetus inside her body by her inhaling human carcinogens ${ }^{6}$ but no legal action can be taken against her simply because the unborn child is not a legal person. ${ }^{7}$

This article aims to stimulate further debate about what is to be done to protect children and spouses from exposure to environmental tobacco smoke at home. First, it presents the evidence against passive smoking and some myths about it. Secondly, it argues that passive smoking at home is child abuse and neglect, parental irresponsibility and spousal abuse, and laments the inadequacy of the law at present to protect the victims of that abuse. It focuses, thirdly, on the inability of the law to allow action to be taken successfully against pregnant women who smoke and, lastly, points out that, although there are some non-coercive and coercive measures that may be taken, the coercive options are so fraught with evidential and other problems that priority should be given to the non-coercive measures.

\section{The Evidence Against Passive Smoking}

Passive smoking should be an issue of increasing concern for everyone simply because it is detrimental to health and has legal implications. It affects the passive smoker's health in many ways, according to various studies.

First, a report on passive smoking released in 1986 by the Surgeon-General of the United States concluded, inter alia, that environmental tobacco smoke causes lung cancer and several other respiratory problems in non-smokers. ${ }^{8}$

Secondly, according to the United States Environmental Protection Agency, after its full review of the evidence establishing the dangers of environmental tobacco smoke:

"- involuntary smoking leads to the deaths by lung cancer of

3,000 non-smokers in America annually;

- environmental tobacco smoke is a human carcinogen, to which no level of exposure is safe; ${ }^{9}$

5 It is quite deplorable that on 2nd May 2001 the Government issued a statement that regulations would be laid before Parliament which would permit childminders to smoke in front of children with the consent of the children's parents. The statement is clearly not one aimed at helping to reduce the exposure of children to environmental tobacco smoke. However, those regulations would require approval by Parliament to become part of the law.

$6 \mathrm{Eg}$, recent research has found a link between smoke exposure during pregnancy and (central nervous system) tumours in offspring (Demott, "Smoke Exposure During Pregnancy Tied to CNS Tumors in Offspring", (1999) Family Practice News, June 1, v 29, i 11, p 46).

7 Re F (in utero) [1988] 2 All ER 193.

8 United States Department of Health and Human Services, The Health Consequences of Involuntary Smoking: a Report of the Surgeon General (1986).

9 A "human carcinogen" is a substance which causes cancer or for which a causeeffect relationship has been established in humans (United States Environmental Agency Report, 1992). Tobacco smoke is now said to contain more than 50 human carcinogens and over 4,700 chemicals (Hoffman and Hoffman, "The Changing 
- environmental smoke worsens (and may help cause) new cases of asthma and also causes annually around 300,000 lower respiratory tract infections in infants and fluid build-up in the middle ear of children." 10

Thirdly, studies have provided evidence to support the connection between environmental smoke and heart disease. ${ }^{11}$

Fourthly, benzo[a]pyrene, a component in cigarette smoke, damages a gene that suppresses tumours. ${ }^{12}$

Fifthly, in March 1998 the United Kingdom Government's Scientific Committee on Tobacco and Health reported that there was clear evidence, based on studies involving thousands of people, which showed that passive smoking increased the risk of lung cancer and heart disease by $26 \%$ and $23 \%$, respectively. ${ }^{13}$ The Report also concluded that passive smoking is a cause of other serious respiratory illnesses, of asthmatic attacks and middleear disease in children, and of sudden infant death syndrome. ${ }^{14}$

On the other hand, the link between passive smoking and increased risk of lung cancer has been strongly criticised by, for example, Professor Robert Nilsson, a toxicologist of Stockholm University. After questioning the biological plausibility of, the "misclassification bias" in, and neglect of socio-economic factors by, some studies like those on which the Government's Scientific Committee on Tobacco and Health based its Report of 1998, he described the risk as "extremely small or even negligible". ${ }^{15}$ Moreover, a ten-year study carried out for the World Health Organisation by the International Agency for Research on Cancer, research which involved the examination of 650 lung-cancer patients and 1,542 healthy people in seven European countries, including Britain, Germany, France and Spain, failed to find a clear nexus between passive smoking and lung cancer. According to the findings, people living or working with smokers have little to fear from passive smoking. ${ }^{16}$

Cigarette 1950-1995”, (1997) 50 Journal of Toxicology and Environmental Health, 307-364.

10 U.S. Environmental Protection Agency, Respiratory Health Effects of Passive Smoking: Lung Cancer and Other Disorders, Washington, DC, 1992, USEPA document EPA/600/6-90/006F.

11 Glantz and Parmley, "Passive Smoke and Heart Disease: Mechanisms and Risk", (1995) 273 JAMA 1047; Steenland, "Passive Smoking and the Risk of Heart Disease", (1992) 267 JAMA 94-99. Also, according to a ten-year research study by scientists at Harvard University, USA (see The Times, 21 May 1997), passive smoking can also worsen heart disease and even double the risk of it.

12 Denissenko, Pao, Tang, and Pfeifer, "Preferential Formation of Benzo[a]pyrene Adducts at Lung Cancer Mutational Hotspots in P53", (1996) 18 Science, October, pp 317, 430.

13 The Times, 30 March 1998.

14 See also "Active resistance to passive smoke", (1998) The Lancet, Editorial, March 21, v.351, n.9106, p.845.

15 The Times, 30th March 1998.

16 The Times, 9 March 1998; The Sunday Times, 8 March 1998. 
Nevertheless, more recent studies have still found clear links between passive smoking and various illnesses/conditions: otitis media, ${ }^{17}$ ill health of babies and children, ${ }^{18}$ acute appendicitis, ${ }^{19}$ increase in cancer-related mutations in newborn babies, ${ }^{20}$ increased risk of stroke in non-smokers (by up to $82 \%$ (men having a higher risk than women)), ${ }^{21}$ cot death and serious respiratory difficulties, ${ }^{22}$ low fertility in women, ${ }^{23}$ and an increased risk of meningococcal disease in children. ${ }^{24}$

Therefore, with its links with various illnesses and conditions, as stated above, passive smoking may be said to be harmful although some people suffer more harm than others. It is, thus, a threat in the home where a parent smokes in the presence of his spouse and/or children. No wonder parental smoking is now an important factor in custody issues in the United States of America, as will be seen below.

\section{Shattering certain myths about passive smoking at home}

It is often argued that increase of ventilation (at home, and so forth) will effectively control environmental smoke. That, however, is incorrect because in fact more than a 1000-fold increase in ventilation is required to have a de minimis risk level at typical smoking rates. Such an increase in the rate of ventilation would be impracticable as it would result in a virtual windstorm indoors. ${ }^{25}$

Another myth is that confining smoking to one side of a room will reduce the effect of environmental tobacco smoke. That again is incorrect because this will only result in the environmental tobacco smoke molecules in the smoking section diffusing into the non-smoking section. ${ }^{26}$

Also, it is said that it is possible to increase ventilation rates in the home by opening windows and using exhaust fans. But that raises several questions. How likely is this practice to be used domestically by every smoker? How

17 Ilicali, "Relationship of Passive Cigarette Smoking to Otitis Media", (199) JAMA, Dec 1, v 282, i 21, p 1990.

18 Beecham, "Passive Smoking affects babies and children's health", (1999) BMJ, April 3, v 318, i 7188, p 947.

19 Montgomery, Pounder, Wakefield, "Smoking in Adults and Passive Smoking in Children are associated with acute appendicitis", (1999) The Lancet, Jan 30, v 353, i 9150 , p 379.

20 Seppa, "Exposure to smoke yields foetal mutations", (1998) Science News, Oct 3 , $\mathrm{v} 154, \mathrm{n} 14, \mathrm{p} 213$.

21 The Times, 17th August 1999 - New Zealand study by Bonita et al.

22 Daily Mail, 4th August, 2000 (research by Jarvis et al, Health Behaviour Unit, University College London).

23 Ford and North, "Smoked Ovaries", (2000) New Scientist, October 7, v 168, i $2259, \mathrm{p} 25$.

24 Dobson, "Smoking in parents increases meningococcal disease risk", BMJ, August 5, 2000, v 321, i 7257, p 319.

25 Repace, "Risk Management of Passive Smoking at Work and at Home", (1994) 13(2) St Louis U Pub L Rev, pp 763-785.

26 Ibid. It is worth noting that a sign in front of a pub or restaurant which reads: "Large non-smoking area within" implies there is a smoking area within. 
practicable is it? What is going to happen in the winter months or when the weather is cold? ${ }^{27}$

\section{Child Abuse And Neglect, Parental Irresponsibility And Spousal Abuse}

Article 19 of the United Nations Convention on the Rights of Children (to which the United Kingdom was a signatory in 1991) requires states, parties to the Convention, to "take all appropriate legislative, administrative, social and educational measures to protect the child from all forms of physical or mental violence, injury or abuse, neglect or negligent treatment, maltreatment or exploitation including sexual abuse". Besides, the Human Rights Act 1998 has incorporated the European Convention on Human Rights into the law of the United Kingdom. Protection of children is contained particularly in Article 3 (of the Convention) which prohibits torture, degrading and inhumane treatment or punishment.

Moreover, as regards Northern Ireland specifically, the Northern Ireland Human Rights Commission (created under section 68 of the Northern Ireland Act 1998), in its Bill of Rights Working Paper on Children and Young People (January 2001), has proposed certain very important provisions setting out the rights of children and young people. Paragraph 3 of the Working Paper states (1) that "in all actions concerning children and young people, . . . the best interests of the child shall be the paramount consideration" and (2) that "the state guarantees to every child and young person in need of care and protection such services and treatment as are necessary for his or her well-being". Paragraph 7 concerns protection of children and young persons from abuse, that is, "all forms of physical or mental violence, inhuman and degrading treatment or punishment, injury or abuse, neglect or negligent treatment, bullying, maltreatment or exploitation, including sexual abuse". Also, according to paragraph 11, "every child and young person has the right to grow up in a stable, safe and loving family environment". ${ }^{28}$

In addition, debate is currently going on about the creation of a Children's Commissioner for Northern Ireland with responsibility for promoting and safeguarding the rights and welfare of children. ${ }^{29}$ In England the Children's Rights Commissioner Bill 2001, and in Wales the Children's Commissioner for Wales Bill 2001, aim to do the same.

However, the law currently still does not protect children in the United Kingdom, in particular, from exposure to the harmful effects of environmental tobacco smoke at home. It does not prohibit parents from exposing their children to environmental tobacco smoke; for example, persistent parental smoking at home in the presence of their children has not been expressly stated, statutorily or otherwise, as child abuse. ${ }^{30}$ In short, as

27 Ibid.

28 The dangers of tobacco and other substances are acknowledged by paragraph 14 .

29 See, eg, Dickson, A Briefing Paper on the Proposal for a Children's Commissioner for Northern Ireland (21 March 2001).

30 In the UK the effects of smoking on children are not mentioned specifically in examples or definitions of abuse or injury but abuse and neglect of children have been made targets (Children Act 1989, s31(2); Children (NI) Order 1995, art 
regards harm to children, there has been overconcern for too long with the notion of actual visible harm, that is, physical abuse, and so forth, so that the harm done by parental exposure of children to passive smoke at home is overlooked.

Child abuse is an umbrella term covering several things all detrimental to children. According to Kotch et al (1999), child abuse and neglect may be defined as acts of omission/commission resulting in physical or mental harm (injury) to a child under 18 years old. ${ }^{31}$ Thus, child abuse may be said to be causing actual or likely harm to the child, harm including both ill-treatment and the impairment of health or development (health meaning physical or mental health, and development meaning physical, intellectual, emotional, social or behavioural development). "Physical abuse" implies "physically harmful action directed against a child" and "usually defined by any inflicted injury such as bruises, burns, head injuries, fractures, abdominal injuries, or poisoning". ${ }^{32}$ Therefore, because of its deleterious impact on the health of children, persistent parental smoking at home which results in exposure of their children to passive smoking may be said to be physical abuse. ${ }^{33}$ Moreover, according to the Columbia Encyclopedia, ${ }^{34}$ "some authorities consider parental actions abusive if they have negative future consequences, for example, exposure of a child to violence or harmful substances, extending in some views to the passive inhalation of cigarette smoke". ${ }^{35}$

Such parental behaviour is also describable as "neglect", which, according to the Department of Health and Social Security, is "the persistent or severe neglect of a child, or the failure to protect a child from exposure to any kind of danger, including cold or starvation, or extreme failure to carry out important aspects of care, resulting in the significant impairment of the child's health or development including non-organic failure to thrive". ${ }^{36}$ Very significant in the definition is "failure to protect a child from exposure to any kind of danger", which may be said to include exposure to environmental tobacco smoke at home. In the United States of America child abuse and neglect are defined by the Child Abuse Prevention and Treatment Act of $1996^{37}$ as "at a minimum, any recent act or failure to act on

50(2)) and are prosecutable (see Children and Young Persons Act 1933, s1, and Children and Young Persons Act (NI) 1968 s20).

31 Kotch, Muller and Blakely, "Understanding the Origins and Incidence of Child Maltreatment", in Gullotta and McElhaney (eds), Violence in Homes and Communities, Issues in Children's and Families' Lives, vol II (1999), p 2.

32 Kempe, Silverman, Steele, Droegmuller and Silver, "The battered child syndrome", (1962) 181 JAMA, 4-11.

33 Anderson, "Parental Smoking: A Form of Child Abuse?", (1994) 77 Marq L Rev, 360, 375-76; and Ezra, "Sticks and Stones Can Break My Bones, but Tobacco Smoke Can Kill Me: Can We Protect Children from Parents that Smoke?", (1994) 13 St Louis U Pub L Rev, 547, 575-86.

34 6th ed 2000.

35 In the author's view, it is battery, pure and simple, where it involves intentional interference with the person of another without lawful justification (Stubbings v Webb [1993] 1 All E R 322).

36 Home Office, Department of Health, Department of Education and Science, Welsh Office, Working Together under the Children Act 1989: a Guide to arrangements for inter-Agency co-operation for the protection of children from abuse (1991).

3742 USC 5101 et seq; Pub L No 104-235. 
the part of a parent or caretaker, which results in death or serious physical or emotional harm, or sexual abuse or exploitation, or presents an imminent risk of serious harm". That definition, too, may be said cover parental exposure of a child to environmental tobacco smoke because environmental tobacco smoke can result in serious physical harm.

Parental smoking in the home could also plausibly be raised as an issue under parental responsibility for provision of medical care, mental and physical needs of a child, stable and satisfactory environment, and so forth. This is because, arguably, exposing a child to environmental tobacco smoke at home is similar in effect to failing to protect him from harm or to provide him with habitable housing: it shows parental irresponsibility and, therefore, constitutes a violation of the paternalistic welfare and protective rights of children. $^{38}$

Thankfully, there is judicial recognition of the ill effects of passive smoking on children in the United States of America. For example, in custody cases there (where it is an important factor) the courts have intervened if passive smoking has a deleterious effect, such as worsening of asthma, on a child. In Mitchell $\mathrm{v}$ Mitchell $^{39}$ the Tennessee Court of Appeal refused to return an asthmatic child to the mother who, against the advice of a paediatrician, continued to smoke in the child's presence. Also, in Montufar v Narot ${ }^{40}$ the New York Supreme Court issued an order to the custodial mother, her relatives and her visitors, that any smoking must take place outdoors and that the children must be removed from any situation/location where they would be exposed to environmental tobacco smoke. Similarly in Roofeh $v$ Roofeh ${ }^{41}$ the New York State Court, relying on its inherent power in matrimonial matters to issue orders safeguarding the health and safety of the husband and the children in question, issued a temporary order restricting the chainsmoking wife from smoking in the presence of the parties' children. ${ }^{42}$ Therefore, where there is a clear effect on a child, for example, he has a particular health problem and his parents smoke, the court (English or American) ought to act to protect him and the non-smoking parent, too, if necessary.

Smoking in the home also arguably constitutes spousal abuse (that is, abuse of the non-smoking spouse by the smoking spouse) in that it exposes the non-smoker to the harmful effects of environmental tobacco smoke (carcinogens, and so forth). However, it may be said that non-smoking spouses consent, expressly or impliedly, to the smoking of their partners at

38 Freeman, The Rights and Wrongs of Children (1983), pp 40-54. The author believes that welfare rights include, inter alia, protection from any cruelty, neglect and exploitation, protective rights being more concerned with protection from overtly negative behaviour and activities like inadequate care, abuse or neglect by parents, exploitation in employment or from environmental dangers.

39 Appeal No 01-A-01-9012-CV-00442, Tenn Ct App; April 26, 1991.

40 Docket No FM 04-1121-8789, NY Sup Ct July 23, 1993.

41525 NYS 2d at 765, (1988).

42 See also Hall, "Secondhand Smoke as an issue in child custody/visitation disputes", (1994) West Va L Rev, vol 97(1), Fall, 115-139; Freinkel, "NonSmokers Find New Cudgel in Custody Fights", Legal Times, Oct 4, 1993, p 2; Momjian and Finkelman, "When Custodial Rights go Up in Smoke", Matrimonial Strategist, Dec 1991, p 3. 
home by choosing to live with them knowing that they smoke. Such a defence may be pleaded in an action for breach of duty, trespass to the person, and so forth. ${ }^{43}$

There are problems, however, with legally categorising smoking in the home as abuse. First, there is the difficulty of proof of abuse $e^{44}$ and of damage to health although there is unlikely to be much problem if a child is already suffering from respiratory or other condition caused or exacerbated by environmental tobacco smoke at home.

Other problems with exposure to environmental tobacco smoke at home being considered child abuse and spousal abuse include the "slippery slope argument" 45 (the difficulty of setting the parameters, that is, of determining how many cigarettes must be smoked before the exposure to the smoke can constitute abuse) and the conflict with parental and interspousal immunity, which are looked at in the section on coercive options below. A further problem area is the position of the pregnant woman who smokes.

\section{The Position Of Pregnant Women Who Smoke}

It is lamentable that not much protection is afforded by the law to a foetus where its interests clash with those of the pregnant woman. Presently in English law a competent pregnant woman can refuse medical treatment needed by the foetus inside her with or without any reason whatsoever. ${ }^{46}$ The reason is that "the unborn child is not a separate person from its mother" 47 and, so, "its need for medical assistance does not prevail over her rights". ${ }^{48}$

Therefore, in the light of the evidence against environmental tobacco smoke and the absence of legal personality on the part of the foetus, a pregnant woman who smokes cannot be liable in negligence for injury to the foetus (it would not be fair, just and reasonable for the law to impose a duty on her ${ }^{49}$ because of her right of self-determination and of bodily integrity $)^{50}$ nor can she be liable in trespass to the person of the foetus. That being so, although it has been advocated that a woman's rights ought to be restricted for the sake of the foetus, ${ }^{51}$ the answer to the question whether the pregnant woman

43 Post.

44 See, eg, Re $M$ [1994] 1 FLR 59; Re P [1994) 2 FLR 751.

45 Wendling, "Smoking and Parenting: Can They Be Adjudged Mutually Exclusive Activities?", (1992) 42 Case W Res L Rev, 1025, 1056.

$46 \operatorname{Re} M B$ [1997] 8 Med LR 217.

47 Indeed, foetuses, according to Justice Blackmun in Roe v Wade ((1973) 410 US 113 at 162, a United States Supreme Court case, "have never been recognised in the law as persons in the whole sense" (p 162).

48 Per Judge LJ in St George's Healthcare NHS Trust v S [1998] 3 WLR 936.

49 Caparo Industries v Dickman [1990] 1 All ER 568.

50 See Scott, "Maternal Duties toward the unborn? Soundings from the Law of Tort", (2000) Med LR, vol 8, Spring, pp 1-68.

51 See, e.g., Shaw, "Conditional Prospective Rights of the Fetus", (1984) 5 J Leg Med, 63; Parness and Pritchard, "To Be or Not to Be: Protecting the Unborn's Potentiality of Life", (1982) 51 U Cin L Rev 257; Simon, "Parental Liability for Prenatal Injury", (1978) 14 Colum J Law \& Soc Probs 47; and Myers, "Abuse and Neglect of the Unborn: Can the State Intervene?", (1984) 23 Duquesne L Rev, 1, 60 . 
smoker has a duty to conduct her life or behave so as not to cause pre-natal harm to the foetus may, therefore, be answered in the negative. If a pregnant woman smokes or drinks excessive alcohol, takes drugs, and so forth, she is arguably breaching a moral duty not to harm the foetus; but it is not appropriate to impose a legal duty on her as the foetus has no separate legal personality. ${ }^{52}$ The Canadian case, Winnipeg Child and Family Services (Northwest Area) v DFG ${ }^{3}$, a case about the lifestyle issue of solvent abuse by a pregnant woman, is instructive here. There the Manitoba Court of Appeal, in the intermediate stages, allowed an appeal against an order of the trial judge committing a pregnant woman (on the ground of her alleged mental illness) to a place of safety and requiring her to stop using intoxicants during the remaining period of her pregnancy. (She already had two children suffering from addiction to chemicals and who were developmentally handicapped.) The Court of Appeal's decision was based on the following grounds: (i) there was no evidence that the woman lacked capacity to organise her life or consent to medical treatment; (ii) the only basis for the trial judge's order could be its benefit to the mother (as the court had no power to seek to protect the unborn child); (iii) as the foetus was not a legal person, there was no ground to restrain the alleged tortuous behaviour of the woman (mother); and (iv) it would be undesirable to create foetal rights to conflict with maternal rights. The Supreme Court of Canada ratified the Court of Appeal's decision in 1997. ${ }^{54}$ It was argued against the pregnant woman in Winnipeg that a woman should owe a duty to "refrain from activities that have no substantial value to a pregnant woman's well-being or right of self-determination and that have the potential to cause grave and irreparable harm" 55 to the subsequently born child. But the majority of the Supreme Court held that a cause of action for maternal prenatal injury would create considerable intrusion into a woman's "right to make choices concerning herself". ${ }^{56}$ McLachlin J quoted approvingly a passage from the Canadian Royal Commission's report on New Reproductive Technologies:

"From the woman's perspective, ... considering the interests of the fetus separately from her own has the potential to create adversary situations with negative consequences for her autonomy and bodily integrity ... . [and] ignores the basic components of women's fundamental human rights - the right

52 An exception to this, regarding driving while pregnant, is the Congenital Disabilities (Civil Liability) Act 1976 s2. The section provides: "A woman driving a motor vehicle when she knows (or ought reasonably to know) herself to be pregnant is to be regarded as being under the same duty to take care for the safety of her unborn child as the law imposes on her with respect to the safety of other people; and if in consequence of her breach of that duty her child is born with disabilities which would not otherwise have been present, those disabilities are to be regarded as damage resulting from her wrongful act and actionable accordingly at the suit of the child." So, it is not the foetus but the live born child who can sue.

53 (1996) 10 WWR 111.

54 (1997) 152 DLR (4th) 193.

55 Ibid 210, per McLachlin J.

56 Ibid. 
to bodily integrity, and the right to equality, privacy and dignity." $" 57$

Despite that, the present state of the law relating to the pregnant woman who smokes is regrettable from the moral point of view. Though it makes sense to say that, because the foetus is not yet a born child, it has no legal personality, it is still a living thing (on its way to being a human being). Therefore, it is morally wrong to allow such a foetus to be exposed to seriously harmful effects of environmental tobacco smoke ${ }^{58}$ simply because restricting a pregnant woman's right to smoke might constitute an encroachment on her autonomy and other rights. It should be legally wrong, too, for a pregnant woman to wilfully expose her unborn child to the human carcinogens and so forth in environmental tobacco smoke because the foetus may be said to have a right to gestation undisturbed by wilful and wrongful injury as well as a right to be born with a healthy mind and body, free from maternally inflicted abuse and/or neglect. ${ }^{59}$

However, enforcement of any such restrictions or law against smoking by pregnant women, it must be admitted, will be very difficult, if not impossible.

So far the evidence against environmental tobacco smoke has been presented and it has been argued that exposure of children and spouses to environmental tobacco smoke at home is child abuse and spousal abuse, respectively. The position of the pregnant woman who smokes has also been looked at. The options available to victims of passive smoking at home will now be considered.

\section{Options And Associated Problems}

Because of the very harmful effects of environmental tobacco smoke both non-coercive and coercive interventions against exposure of environmental tobacco smoke at home seem desirable. However, as will be shown, the coercive options are fraught with various difficult problems, some of them insurmountable.

\section{Non-coercive measures}

By way of extensive publicity and education, the Government must make the public aware of the deleterious effects of environmental tobacco smoke at

57 Proceed with Care (1993), vol 2, 957-8. Though this will not necessarily be applauded by those who want to see restrictions imposed on a pregnant woman for the sake of the foetus, the English Court of Appeal in St. George's Healthcare NHS Trust v S, R v Collins and Others, ex parte $S$ [1998] 3 WLR 936 at 957 agreed with, at 690 agreed with the reasoning of the majority in the Winnipeg case.

58 Subject to exceptions (e.g., medical reasons), it is also morally wrong for the law to permit abortion.

59 See, eg, Myers, "Abuse and Neglect of the Unborn: Can the State Intervene?", (1984) 23(1) Duquesne L Rev, 60; Shaw, "Conditional Prospective Rights of the Fetus", (1984) 5 J Leg Med, 63; Parness and Pritchard, "To Be or Not to Be: Protecting the Unborn's Potentiality of Life", (1982) 51 U. Cin L Rev, 257; and Simon, "Parental Liability for Prenatal Injury", (1978) 14 Colum J Law \& Soc Probs, 47. 
home and also of tobacco smoking in general. Such public education programmes would also help reduce the prevalence of smoking among parents and pregnant women and therefore protect children, spouses and other relatives at home from the said ill effects.

In addition, family doctors (general practitioners) and other health workers who come into contact with parents ought to be encouraged to stress to parents and pregnant women who smoke the dangers of environmental tobacco smoke, to advise them against the habit of smoking and even help them to stop. The soundness of this non-coercive measure is supported by research findings that parents who smoke who have been advised by a doctor not to smoke when their children are around will eventually expose those children to fewer cigarettes. ${ }^{60}$

\section{Coercive Options}

\section{(a) Invoking the parens patriae jurisdiction}

Whereas adult victims can move out of the matrimonial home at least temporarily, a baby victim, however, has no choice but to stay and continue to suffer exposure to environmental tobacco smoke because of dependency on his/her parents. The Queen (the Sovereign) has the prerogative right to take care of both the persons and estates of minors. ${ }^{61}$ However, the exercise of those prerogative powers has now been delegated or statutorily assigned to various bodies/authorities; for example, jurisdiction in respect of wardship of minors and care of their estates has now been assigned to the Family Division of the High Court, ${ }^{62}$ and duties in respect of children in need of care and control are now in the hands of local authorities. ${ }^{63}$ The court can, therefore, step in to protect the infant.

But, what form should the protection take? Should the child victim be made a ward of court? Separating a child from his/her parents one way or another is generally not good for the child; it would also be contrary to the ideal of promotion of family unity/cohesion which is conducive to the child's upbringing; it may even be contrary to public policy. Moreover, an order banning parental smoking at home will lead to a lot of controversy because smoking itself is not illegal. Restricting parental smoking to a particular room of the matrimonial home would be less controversial but the problem with that is enforcement of the restriction. Also, should the smoking parent be prosecuted under, for example, section 1 of the Children and Young Persons Act 1933 (or Children and Young Persons (NI) Act 1968) for abusing or neglecting the child exposed to environmental tobacco smoke at home? Again, certain problems exist with this measure. It may militate against the notions of family unity and harmony and of parental immunity from suit by a child. In addition, will abuse or neglect be constituted by

60 Murray and Morrison, "The decrease in severity of asthma in children of parents who smoke since the parents have been exposing them to less cigarette smoke", (1993) 91 J Allergy Clin Immunol, 102-110.

61 As well as mentally disordered persons.

62 Certain restrictions on the use of the wardship jurisdiction are, however, set out in Children Act 1989 s100. As regards Northern Ireland, see the Children (NI) Order 1995, Art 173(1).

63 Children Act 1989 s.33; see also Children (NI) Order 1995, Art 52. 
exposure to the smoking of one, two, ten, twenty or forty or more cigarettes a day? Where do you stop? This is the problem of the "slippery slope argument" again.

\section{(b) Trespass to the person (specifically battery)}

Battery is the direct and intentional application of force to the person of another without lawful justification; ${ }^{64}$ therefore, the least touching of another person or an unwanted kiss constitutes battery. ${ }^{65}$ If spitting on a person is battery, ${ }^{66}$ then it is arguable that making someone smoke passively (that is, blowing poisonous smoke onto someone thereby causing him to inhale it) should also be battery. ${ }^{67}$ Consequently, all that a claimant must be required to show on a balance of probabilities is that the defendant, without lawful justification, blew his unwanted smoke on him or caused that smoke to touch him (the claimant). However this is a different kind of passive smoking to the one discussed in this article (involuntary exposure to tobacco smoke).

It is submitted that the victim is unlikely to succeed in an action based on assault simply because the test of immediacy of the battery feared will not be satisfied. ${ }^{68}$

Trespass requires actual physical contact. It is thought that this requirement would not be very difficult to satisfy because the vaporous and particulate matter found in environmental tobacco smoke could be a sufficient basis for establishing the necessary contact. For example, in an American case, Davis v Georgia Pacific Corp ${ }^{69}$ it was held that deposits of airborne particulates on another person's land constituted trespass although particulates were too small to be seen.

${ }^{64}$ See Coyle v Reid and another [2001] NI 7 (Court of Appeal).

65 Collins v Wilcock [1984] 3 All ER 374. See also Copeland v Ministry of Defence and anor [1999] NIJB 234. Where there is intention on the defendant's part, the cause of action should be trespass to the person (specifically, here, battery) and, where there is no intention, negligence should be the cause of action; see Letang $\mathrm{v}$ Cooper [1965] 1 QB 232, 240 (per Lord Denning MR); see also Stubbings v Webb [1993] AC 498, where the House of Lords did not allow the plaintiff to treat an intentional personal injury (trespass to the person) as negligence in order to gain an advantage as regards the limitation of actions. For a lucid account of the historical controversy about whether there could be liability for trespass without negligence see Jones, Textbook on Torts, 7th ed (2000), pp 462-3.

$66 R$ v Cotesworth (1704) 6 Mod Rep 174, where the defendant spat on a medical doctor; see also $R$ v Smith (1866) 176 ER 910.

67 See McCartney, "Not smoking can damage your health", (1988) 138 NLJ, 425-6. Also, in the USA, a Georgia Court of Appeals has held that an employee, who alleged battery by a co-worker's smoking of a pipe near her workstation, could sue for battery (Richardson v Hennly, 434 SE 2d 772 (1993)).

68 Thomas v NUM [1985] 2 All ER 1. Arguably, if a smoker exhales tobacco smoke, the non-smoker does not immediately inhale that exhaled smoke unless the smoker exhales directly into the face of the non-smoker. The success of such an action, if it does happen, will open the floodgates of litigation (every time a person smokes a cigarette in a smoking or no-smoking area, he can, in theory, be sued for assault by the non-smokers present in that area). So, the courts are not likely to allow that to happen.

69455 P 2d 481, 483 (1968). 
Nevertheless, an action for trespass (to the person) by a child against his parent or by one spouse against the other spouse is likely to violate the concept of parental immunity and interspousal immunity (all considered below) which are thought to preserve domestic tranquillity/harmony. If so, then there is a strong public policy ground for rejecting such course of action. These problems also face any action for nuisance, negligence and breach of duty under the Occupiers' Liability Act $1957 .{ }^{70}$

\section{(c) Nuisance}

The non-smoking spouse (victim of passive smoking at home) may also want to sue the smoking spouse for private nuisance, which is the unlawful interference with a person's use and enjoyment of land or some right or interest over it. Thus, he/she must have an interest in land, ${ }^{71}$ something children do not usually have in their home. The "intangible or amenity damage" 72 here is the personal discomfort to the victim caused by the environmental tobacco smoke. ${ }^{73}$

One question that needs to be answered here is whether smoking at home is reasonable use of land like eating or drinking at home. It may be said that, whereas eating and drinking at home at worst directly harm only the actor (eater/drinker), smoking at home so as to expose the smoker's children and/or spouse to environmental tobacco smoke directly affects the health of both the active smoker and passive smoker and, therefore may constitute unreasonable use of land.

Unfortunately, there seems to be no case illustrating the position of a person suing his/her spouse for nuisance under such circumstances. For this reason, not to mention the preservation of family harmony/tranquillity, this option is not recommended.

\section{(d) Negligence}

To succeed here, where there is no intention to do harm by the smoker, ${ }^{74}$ the victim must show, first, that he was owed a duty of care by the smoker. ${ }^{75}$ This, by virtue of the parent-child or spousal relationship, would probably not be difficult to prove. ${ }^{76}$ He must also show that the duty so owed to him was breached ${ }^{77}$ by the smoking spouse/parent (by exposing him/her at home

70 Post.

71 Hunter v Canary Wharf [1997] 2 All ER 426, which overruled Khorasandijan v Bush [1993] 3 WLR 476 on this point and upheld the decision in Malone v Laskey [1907] 2 KB 141. See also O'Kane v Campbell [1985] IR 115.

72 Jones, op cit, p 307.

73 See Bolton v Stone [1951] AC 850, where in a claim in respect of her physical injury, the claimant sued in negligence and nuisance.

74 Where there is such intention, the action must be brought in trespass (Letang $\mathrm{v}$ Cooper [1965] 1 QB 232).

75 See Donoghue v Stevenson [1932] AC 562; Caparo Industries plc v Dickman [1990] 1 All ER 568; Marc Rich \& Co. AG and others v Bishop Rock Marine Co. Ltd [1995] 3 All ER 307. See also Joy v Newell (t/a The Copper Room) [2000] NI 91 (Court of Appeal).

76 See, eg, Alcock v Chief Constable of South Yorkshire; Surtees v Kingston-uponThames Borough Council; Surtees v Hughes and Another [1991] 2 FLR 559.

77 Paris v Stepney Borough Council [1951] AC 367. 
to, or failing to protect him/her at home from, environmental tobacco smoke, which is known to contain carcinogenic and asthma-promoting substances) and that the damage he suffered was caused by that breach of duty. ${ }^{78}$

On the issue of proof of harm/injury, although there is a lot of evidence of the deleterious effects of environmental tobacco smoke, one crucial question is whether environmental tobacco smoke has really injured the child/spouse in question? Medical examination of child/spouse may be required for this. Another crucial question is how many cigarettes a parent has to smoke for harm to be established, although it is today possible to detect the extent of environmental tobacco smoke inhalation by measuring chemicals from the smoke in the victim's urine, saliva and blood. A further problem is whether the mere presence of chemicals in the victim's blood, and so forth, is sufficient to constitute harm/injury. Also, if the child or spouse is not confined to the home, how can exposure to environmental tobacco smoke at home be distinguished from exposure to environmental tobacco smoke (from the smoking of strangers) outside the home for the purpose of assessing damage/injury to him/her? ${ }^{79}$

\section{(e) Occupiers' Liability}

A victim (child or spouse) who, without interest in land cannot sue in nuisance ${ }^{80}$, can still sue under the Occupiers' Liability Act 1957.81 A child or spouse who has no present right of ownership of the matrimonial home can argue that he/she is living in the home as a "visitor" (he/she has both permission and invitation (impliedly if not expressly) to live there. ${ }^{82} \mathrm{But}$, is a home which is periodically or continually filled with tobacco smoke (or "unclean air") "unsafe" or "dangerous" premises? If it is considered so because environmental tobacco smoke contains carcinogenic and asthmapromoting substances, or the like, then the victim can claim the smoking parent/spouse has breached the common duty of care, that is, the duty to take such care as is reasonable in all the circumstances to ensure he/she is reasonably safe in the home for the purpose of living there (section 2(1) and (2) Occupiers' Liability Act 1957 or the Occupiers' Liability (NI) Act 1957)..$^{83}$

\section{(f) Family Court orders}

Family Court orders for (i) protection of children (via restraint of the smoker and restriction of parental rights) and (ii) protection of spouses (via restraint of the smoker) may also be sought by the victim. The protection of children has already been looked at above.

78 Overseas Tankship (UK) Ltd v Morts Dock \& Engineering Co, The Wagon Mound [1961] AC 388; Pickford v Imperial Chemical Industries [1998] 3 All ER 462.

79 Note also the problem of parental immunity and interspousal immunity.

80 Hunter v Canary Wharf [1987] 2 All ER 426.

81 The equivalent statute in N. Ireland is the Occupiers' Liability (NI) Act 1957.

82 No matter how unacceptable or outrageous the term, "visitor" may seem in this context, the legal position is still that the child is usually in the home lawfully (not as a trespasser). The spouse living in the matrimonial home can also argue the same.

83 Note, however, the possible defence of consent of the claiming spouse and the problem of the slippery slope argument. 
As regards spouses most of the points here concern common-law spouses, too. Because of the deleterious effects of environmental tobacco smoke, spousal smoking at home ought to be regarded as unreasonable behaviour ("spousal abuse"), as already stated. Thus, in the first instance, an injunction can be sought from the court against the smoker; the smoker can be ordered to smoke only in a designated area of the house or, better still, not to smoke in the house at all. As a last resort, an order may be sought ousting/excluding the smoker from the matrimonial home or parts of it.

However, there is a major problem with this measure, too. It is the undesirability (from the points of view of social work and public policy) of separating a child from his/her parent(s) because of parental smoking at home when smoking itself is not illegal. Restraint of smoking at home would also operate against interspousal immunity and preservation of family harmony/domestic tranquillity.

\section{(g) Criminalising smoking at home}

The important part played by restrictions on smoking at home (and in the workplace) in promoting repeated abstention from smoking, which in turn reduces the exposure of children, and so forth, from environmental tobacco smoke, has been shown by recent research. ${ }^{84}$ So, another option is for the state to criminalise/punish smoking at home just like child abuse and spousal violence. ${ }^{85}$ At least such an intervention is, apart from punishment of the offender (retribution or giving the offender his/her just deserts), intended to attain the objectives of both individual prevention (deterring the offender in question) and general prevention (which is concerned more with the psychology of law-abiding people than with the psychology of criminals). ${ }^{86}$

However, like the other coercive measures, this option is fraught with several problems:

- first, there is the difficulty or impossibility of enforcement. How can parental smoking or spousal smoking at home be made a crime and enforced as such when tobacco smoking at home itself is not a crime? ${ }^{87}$ Besides,

84 Farkas, Gilpin, Distefan and Pierce, "The effects of household and workplace smoking restrictions on quitting behaviours", Tobacco Control, 1999, 8: 261-5.

85 By way of analogy, it has been argued that parental use of drugs/alcohol during pregnancy is also child abuse because of pre-natal injuries (see, eg, Ellen L. Townsend, "Maternal Drug Use During Pregnancy as Child Neglect and Abuse", (1991) 93 W Virginia L Rev 1083. However, see the Winnipeg case, op cit $\mathrm{n} 53$.

86 See Andenaes, Punishment of Deterrence (1974, p 42); although punishment on the basis of deterrence is unjust because the criminal then suffers punishment not for what he has done but to induce others to avoid crime, i.e., treating him, not as an end in himself but only, as a means to someone else's end [Bittner and Platt, "The Meaning of Punishment", (1966) 2 Issues in Criminology, 79-99, at p 93] (which is contrary to the moral principle of Kant that man must always be treated as an end in himself (Kant, "Metaphysische Anfangsgrunde der Rechtslehre", zweiter Teil, erster Abschnitt, Das Staatsrecht Allgemeine Anmerkung E (1797); Hill, Jr, "Kant on wrongdoing, desert and punishment", (1999) Law and Philosophy, July, v 18, i 4, pp 407-441).

87 Smoking at home, if criminalised, will thereby belong to the class of acts illegal because of legal prohibition, mala quia prohibita (and not because they are immoral by themselves, mala per se). 
banning smoking altogether is too controversial and entangled with politicoeconomic matters (for example, the issue of revenue from tobacco) to be a realistic goal or solution in today's society. ${ }^{88}$ Therefore, legislation banning smoking at home is also unlikely;

- secondly, there is the "slippery slope" argument. Where do you stop? Do you punish the smoking of 5, 10, 20 or 40 cigarettes at home? If parents are not punished for giving their children sweets and high-cholesterol foods, why should they be punished for exposing their children to environmental tobacco smoke at home? This is a question that many people may well ask; and

- there is, moreover, the problem of such prohibition encroaching upon the sanctity of the home and parental rights. ${ }^{89}$ However, though state intervention against exposure of children (and spouses) to environmental tobacco smoke at home may be said to violate the Human Rights Act 1998, Schedule 1, Part 1, Article 8(1), that is, the right to respect for private and family life, home and so forth, such intervention is justifiable under Article $8(2)$ as being necessary "for the protection of health" or "for the protection of the rights" of children (and spouses) so exposed since environmental tobacco smoke is known to be dangerous to health, as already indicated. The sanctity of the home and parental rights will now be looked at.

\section{Parental Immunity}

The family has been traditionally regarded by the law as a private realm which should not be interfered with. On the position in English law, Lord Bowen stated in Re Agar-Ellis, Agar-Ellis v Lascelles: "Both as regards the conduct of private affairs and domestic life, the rule is that the courts of law should not interfere except upon occasion." 90 So, parents have been regarded (though not in all cases) as immune from being sued by their children. For example, where parents use reasonable force to chastise their child, an action by the child against them for trespass to the person will fail. ${ }^{91}$

Parental immunity has been advocated on the following grounds: (a) the desire of the courts to maintain family harmony (domestic tranquillity); ${ }^{92}$

88 Even if, because law-making being an "enterprise" (Becker, Outsiders (1997), the whistle is blown by some person(s), eg, child protection agencies and "antinicotinists" (Fogg, "Two views of law and social process", (1992) 17 UQLJ, 1 at 16-18), loudly enough to be heard.

89 It must be noted that parental immunity and spousal immunity also stand in the way of other types of legal action (eg, suits in negligence, trespass, nuisance, etc, as pointed out above) by children against their parents and spouses against their spouses.

90 (1883) Ch D 317, at 335. See also Conaghan, "Tort Litigation in Intra-familial Abuse", MLR, March 1998, 132-161, at 136-7. On the position in the United States of America concerning the traditional immunity of parents against tort actions by their children see Keeton et al, Keeton and Prosser on Torts, \#122, at 905-910 (5th ed, 1984); Pipino, "In Whose Best Interest? Exploring the Continuing Viability of the Parental Immunity Doctrine", (1992) 53 Ohio St LJ, $1111-1133$

91 See, eg, s1(7), Children and Young Persons Act 1933.

92 See Hill v Hill, 415 So 2d 20 (Fla 1982); Davis v Grispoon, 570 NE 2d 1242 (Ill 1991); Schlessinger v Schlessinger By and Through Schlessinger, 796 P 2d 1385 (Colo 1990); Pipino, op cit n 90, pp 1112-3). Note, however, that, where a child 
(b) the courts' worry about the possibility of collusion, that is, parents and children might collude or team together to bring fabricated claims ${ }^{93}$ in other words, children with a diagnosis for environmental tobacco smoke-related diseases could collude with parents to commence litigation designed to compel liability insurers to pay the family money $;{ }^{94}$ (c) parent-child litigation might result in the excessive erosion of parental discipline and authority; ${ }^{95}$ (d) preventing the parents' potential acquisition of the child's tort damages via intestate succession should the child die first; ${ }^{96}$ and (e) preserving the family exchequer (that is, funds for the entire family's life necessities) from depletion via damages against the parents. ${ }^{97}$

The arguments against the immunity (which include the following: benefit to the litigant child's health, compensation for truly injured children and possible encouragement of parents to consider not smoking at home or in the presence of their children), ${ }^{98}$ however, do not seem to outweigh the arguments for it, especially, promotion of family harmony which, it is thought, accords with public policy. ${ }^{99}$ Therefore, parental immunity provides a strong reason why non-coercive (rather than coercive) measures should be employed to address the problem of exposure of children to environmental tobacco smoke at home.

\section{Interspousal Immunity}

Interspousal immunity from suit may be said to have resulted from the traditional attitude of the law of generally not subjecting the family to regulation. But, there is now recognition that the law has a significant role to play in family matters and the concept of interspousal immunity, like parental immunity, has been under attack. ${ }^{100}$ It has now been removed from English law and is being eliminated in the U.S.A. ${ }^{101}$

Because of the traditional non-interference with family privacy, a wife could not, before 1962, sue her husband in tort (and vice versa), for example, for battery. However, now such action is possible, under the Law Reform (Husband and Wife) Act 1962 which provides, inter alia, that where a family member is assaulted by another physically or sexually, there is a right to sue

has suffered injury due to parental action, the familial harmony has already been disrupted and, therefore, parental immunity is not a bar to the child's action: Hurst v Capitell, 539 So 2d 264 (Ala 1989).

93 Davis v Grispoon ibid.

94 Pipino, op. cit n.90, p 1114.

95 Ezra, "Sticks and Stones Can Break My Bones, But Tobacco Smoke Can Kill Me: Can We Protect Children From Parents That Smoke?" (1994) St Louis U Pub L Rev, 13(3), 547-590, at 583. However, parental authority ought not to cover the right to expose the child to risks undertaken for the parent's personal gratification.

96 Roller v Roller ibid, 79 P 788 (1905); Pipino, op cit $\mathrm{n}$ 90, pp 1113-4.

97 Roller v Roller; Pipino, op cit $\mathrm{n}$ 90, p 1114.

98 Ezra, op cit $\mathrm{n} .95, \mathrm{pp}$ 583-4.

99 See, eg, Wroth v Tyler [1974] Ch 30; [1973] 2 WLR 405.

100 Conaghan, op cit $\mathrm{n}$ 90, pp 136-7.

101 Where, regarding negligent and intentional tort actions (see, eg, Waite v Waite, 618 So 2d 1360 (Fla 93), (cancelling all interspousal immunity from tort); see also, Kelly, "Transcending Borders: Escaping the Confines of Gender Violence", in Trubek and Cooper (eds), Educating for Justice Around the World (1999), ch $10,195, \mathrm{n} 22$. 
for damages, except that the court can stay proceedings if it concludes that continuance of the action would not result in substantial benefit accruing to either party. ${ }^{102}$

The problem here, again, is whether it is not better to preserve family harmony than to interfere with it or possibly disrupt it by allowing one spouse to sue the other for doing something which in itself is not illegal. So, it is felt that a suit by a spouse in respect of exposure to environmental tobacco smoke at home will not result in substantial benefit to either party. This would justify the application of section 1(2)(a) of the Act of 1962.

\section{Conclusion}

It cannot be seriously disputed that environmental tobacco smoke is harmful to health. The evidence against environmental tobacco smoke is, as already stated, overwhelming. Passive smoking at home is clearly an important but controversial topic which shows a clash of rights: the smoker's right to smoke against the non-smoker's right not to be put at risk healthwise. The health hazards, as shown by the various scientific studies on the effects of environmental tobacco smoke, are so serious as to justify classification of exposure of a child and spouse to environmental tobacco smoke at home as child abuse and spousal abuse, respectively, and, so, to seem to warrant the taking of both non-coercive and coercive measures (against the phenomenon).

However, tobacco smoking itself is not illegal. Moreover, the law today is clearly inadequate to protect children and spouses from exposure to environmental tobacco smoke at home. Unfortunately, there are enormous problems facing the coercive measures available against such exposure of children and spouses. Those problems range from evidential issues to public policy. Accordingly, it is recommended that the non-coercive measures be given precedence.

$102 \mathrm{~S} 1(2)(\mathrm{a})$. The equivalent statute in Northern Ireland is the Law Reform (Husband and Wife) Act (NI) 1964. See also Conaghan, op cit $\mathrm{n}$ 90, pp 138-9. 